\title{
ЛЕКСИКОЛОГІЯ
}

УДК 811.161.2.373.46;625

Н. П. Книшенко

\section{ПОНЯТТЯ «ЛЕКСИКО-СЕМАНТИЧНЕ ПОЛЕ» Й «ТЕРМІНОЛОГІЧНЕ ПОЛЕ» В СУЧАСНОМУ МОВОЗНАВСТВI}

У статті зауважено, що використання тінгвістичних термінів «лексико-семантичне поле» й «термінологічне поле» в сучасному мовознавстві ускладнюється існуванням їхніх різних тлумачень. Узв'язку із иим видається доиільним з'ясувати поняттєві обсяги відповідних лінгвістичних термінів і визначитися зі способом іх уживання. Висновковуємо, що поняття «термінологічне поле» в межах дослідження будь-якої термінологічної системи (ТС) корисне для констатаиії належності певної лексичної одиниці як терміна до відповідної термінологічної системи, а поняття лексико-семантичного поля важливе для вивчення системної організації термінів відповідної галузі знання як мовних одиниць.

Ключові слова: ЛСВ - лексико-семантичний варіант, ЛСГ - лексико-семантична група, ЛСП - лексико-семантичне поле, ТП - термінологічне поле, ТС - термінологічна система.

Knyshenko N. The Concepts "Lexical Field" and "Terminological Field" in Modern Linguistics. In modern linguistics, the issue of studying the lexical system of a language (semantic fields, semantic and thematic groups, etc.) is relevant. Studying any terminology in the context of identifying its system organization as a branch terminological system is impossible without resorting to such concepts as "lexical field" and "terminological field".

It is noted that the use of linguistic terms "lexical field" and "terminological field" in modern linguistics is complicated by the existence of their various interpretations. In this regard, it seems appropriate to clarify the denotative meanings of the corresponding linguistic terms and determine the way of their using.

In the study, with the application of the analytical method, which covers conceptual, comparative, semantic, logical semantic analysis, the scientific validity and applicability of the concepts "lexical field" and "terminological field" is determined.

Based on the findings of Ukrainian linguists L. A. Lysychenko, O. A. Oleksenko, T. I. Panko, B. O. Plotnikova, O. O. Reformatorskyi, F. P. Filin, and others, we conclude that the terminological field is the sphere for realizing the possibility of a certain lexical unit to be directly correlated with the concept, and therefore, be a term. Within 
the framework of the terminological field, terms are in system connections and relations, which provide the above possibility of a certain lexical unit to be a term. In other words, the whole complex of terms within the terminological field is the realization of the terminological system as a formation that reflects the system knowledge of the corresponding science about the matter of its study. Along with this, the lexical field is a structurally and semantically organized set of terms, which, on the one hand, reflects the knowledge structure of the corresponding scientific field (thematic group), and, on the other hand, is subject to the intralinguistic laws of the organization of vocabulary, which is manifested in its grouping according to certain signs (differential ones) into different subgroups (lexical variants).

Key words: $L V$ - lexical variant, $S G$ - semantic group, $L F$ - lexical field, TF terminological field, TS - terminological system.

\section{Вступ}

Вивчення будь-якої термінології в аспекті виявлення ії системної організації як галузевої ТС $є$ неможливим без звернення до таких понять, як «лексико-семантичне поле» й «термінологічне поле». Слід зауважити, що використання цих лінгвістичних термінів ускладнюється існуванням їх різних тлумачень: одна група дослідників ставить між цими поняттями знак рівності, друга група стверджує недоцільність використання одного з термінів, третя - указує на самостійність цих наукових категорій і окремішність понять відповідних терміноодиниць. У зв'язку із цим видається доцільним з'ясувати поняттєві обсяги відповідних лінгвістичних термінів і визначитися зі способом їх уживання.

\section{Методи та методики дослідження}

У дослідженні застосовано аналітичний метод, що дає змогу з'ясувати наукову обгрунтованість і доцільність таких понять, як «лексико-семантичне поле» й «термінологічне поле», і охоплює методи концептуального, порівняльного, семантичного, логіко-поняттєвого аналізу.

\section{Результати та дискусії}

На думку О. В. Суперанської, для будь-якого терміна дуже важливу роль відіграє термінологічне поле (ТП), у яке він входить і поняття якого позначає. Для спеціаліста достатньо буває згадування цього поля, щоб термін сприймався ним однозначно й не потребував жодних дефініцій. Згадування поля може замінюватися введенням 
терміна в контекст, що допомагає в цьому разі міркувати: до хімії, фізики чи ботаніки належить той чи той термін (Суперанська, 1976: 77; 81).

О. О. Реформатський має такі міркування щодо порушеної проблеми: 1) той самий термін стосовно різного ТП (тобто коли він входить у різні термінологіi) - не те ж саме, оскільки зв'язки поняття, що фіксуються цим терміном, різні для різних дисциплін, що й визначає його поле: 2) поле (Feld) для терміна - це певна термінологія, поза якою слово втрачає свою характеристику терміна (Реформатський, 1961: 51). Отже, вслід за О. О. Реформатським, можна констатувати, що співвіднесені поняття вказують на «ідіоматичність» ТП для кожної термінології, тобто всі основні риси притаманні термінам лише в межах свого ТП.

Терміни в межах свого поля об’єднуються навколо ядра. Ядро для ТП - це базове поняття, що виражає загальне значення від центру до периферії поля. Терміни на периферії більш активно взаємодіють з іншими суміжними полями. Усі ТП перетинаються та взаємодіють між собою. Науковці вважають концептуальною проблемою під час дослідження термінологій виявити «детермінанти, що призводять до організації термінів у систему, специфічних засад, зв'язків і відношень у кожній конкретній системі, їі особливої якості, встановлення закономірностей структури функціонування й розвитку цієї системи» (Панько, 1994: 179).

Поняття «термінополе» позначає сферу чинності певної лексичної одиниці як терміна відповідної галузі наукового знання. Поза цим полем відповідна лексична одиниця або може зовсім не сприйматися як термін (наприклад, лисиия як назва тварини в буденній мові не $є$ терміном, а лисиия як назва допоміжного елемента в дерев'яних мостах є терміном), або ж може сприйматися як термін іншої галузі знання, а отже, як одиниця, що має подібний чи зовсім відмінний поняттєвий обсяг (наприклад, амортизація як термін у будівельній індустрії та як термін в автомобільній та економічній індустрії). Таким чином, термін як особлива лексична одиниця, що безпосередньо позначає поняття певної галузі знань, входить у ТП цієї галузі, де всі терміни пов'язані між собою в чітко окреслену ТС. 3 огляду на це кожен окремий термін з чітко окресленою дефініцією може використовуватися тільки в певному ТП. 
У сучасній лінгвістиці актуальним є питання вивчення лексикосемантичної системи мови (семантичних полів, лексико-семантичних і тематичних груп тощо). Узявши за основу висновки лінгвістів про те, що терміни в процесі функціонування в професійних сферах спілкування фахівців набувають деяких специфічних особливостей, що, однак, не виводять їх за межі мови, оскільки всі ці особливості не протистоять ні системі, ні структурі природної мови (Даниленко \& Волкова, 1993: 3), терміни розглядають як одиниці природної національної літературної мови.

Подвійна назва (лексико-семантична) сигналізує про те, що слова аналізуються як лексеми в усіх їх формах і лексичних значеннях і що об'єднання слів як одиниць словникового складу здійснюється за основною ознакою - за семантикою слова.

Як відомо, лексичне значення є важливим інструментом закріплення в мові результатів пізнавальної діяльності людини. Упорядкованість цієї лексики досягається шляхом згрупування лексем за ознаками, вибраними з погляду використання в процесі комунікації. А от семантичні ознаки слугують будівельним матеріалом для плану змісту мови. 3 їх допомогою одні слова відрізняються від інших, тобто ознаки здійснюють диференційну функцію, інші слова об’єднуються між собою в різні парадигматичні угруповання (Плотніков, 1984: 66).

Таким чином, семантична ознака може виконувати одночасно дві функції: групувати лексичні одиниці й роз'єднувати (на підставі інтегральних і диференційних сем). Семантичні ознаки $є$ компонентами значення окремої лексеми, а також компонентами, що організовують лексеми в лексико-семантичні групи. 3 огляду на це саме за взаємозв'язками семантичних значень лексика поділяється на ЛСП. На думку С. Г. Шафікова, поняття «лексико-семантичне поле» дозволяє інтегрувати в таксономію полів тип, що називається в лінгвістиці ЛСГ, яка складається з полісемантів, об'єднаних за основним значенням (Шафіков, 1999 : 22).

Тож у межах тематичних мікросистем виділяються ЛСГ - мовні об’єднання слів, що базуються на парадигматичних відношеннях. Здатність слова входити до різних лексичних угруповань в мовленні свідчить про те, що до структури його змісту входить сукупність семантичних ознак, які зумовлюють групування слів, що пов'язані 
в полі різними ієрархічними зв'язками. Слушною й прийнятною для нашого дослідження є теза Н. І. Овчаренко, що ЛСП термінів окремих галузей постають як організовані системи взаємопов'язаних і взаємозумовлених елементів, об'єднаних у ЛСГ і лексико-семантичні підгрупи, що визначились на підставі денотативних ознак (Овчаренко, 1997: 48).

На думку Л. А. Лисиченко, «лексико-семантичне поле як група слів становить собою велике угруповання ЛСВ (лексико-семантичних варіантів), що пов'язані одним відрізком дійсності і належать до різних частин мови». Автор розрізняє поняття лексико-семантичні поля й тематичні групи, при цьому зазначаючи, що «тематична група складається за денотативним компонентом лексичних значень, тому є, так би мовити, більш «грубою» порівняно з семантичним полем, бо не враховує внутрішньомовних відмінностей між значеннями слів» (Лисиченко, 1997: 122-123). Незважаючи на проведене розмежування, науковець підкреслює єдність принципів організації лексики й невід'ємність класифікації за ЛСГ від тематичної класифікації. О. А. Олексенко також уважає, що між ними є багато спільного й доводить у своєму дослідженні, що «термін «тематична група» можна вживати паралельно з терміном «семантична група», оскільки групи слів, об’єднані на основі предметно-логічної спільності, здебільшого характеризуються й деякими спільними для них мовними ознаками (Олексенко, 1999: 28).

Ф. П. Філін дотримується думки, що будь-яка ЛСГ має свою тему й що «в межах однієї тематичної групи існують більш дрібні, але тісно пов'язані між собою лексико-семантичні групи слів». Кожна ЛСГ, таким чином, «входить в те чи те тематичне об'єднання слів, будучи його складником» (Філін, 1957: 527).

\section{Висновки}

Отже, ЛСП можна визначити як складну мікросистему лексичних одиниць, об’єднаних планом змісту й формальних показників, що відображають поняттєву, предметну або функціональну подібність позначуваних явищ, ця мікросистема має низку властивостей, найважливішими 3-поміж яких є: наявність центру й периферії, iєрархічний принцип побудови, відсутність чітких меж, незамкненість, взаємодія з іншими полями, здатність притягувати до себе елементи 
інших груп. Термінологічне поле - це сфера реалізації можливості певної лексичної одиниці бути безпосередньо співвіднесеною з поняттям, а отже, бути терміном. У межах ТП терміни перебувають у системних зв'язках і відношеннях, які й забезпечують зазначену вище можливість певної лексичної одиниці бути терміном. Іншими словами, увесь комплекс термінів, що чинні в межах ТП, є реалізацією ТС як утворення, що відбиває системні знання відповідної науки про об'єкт ії вивчення. Поряд із цим ЛСП - це структурно й семантично організована сукупність термінів, що, з одного боку, відбиває структуру знань відповідної наукової галузі (ТГ), а з другого, - підпорядкована внутрішньомовним законам організації лексики, що виявляється в ії групуванні за певними ознаками (диференційними) в різні підгрупи (ЛСВ).

Перспективи досліджень убачаємо в розгляді польової структури терміносистеми будівельної галузі, де за основу взято низку ознак термінологічного поля й лексико-семантичного поля, визначених у статті.

\section{ЛІТЕРАТУРА}

1. Даниленко В., Волкова І. Лингвистический аспект стандартизации терминологии: монографія. Москва: Наука, 1993. 127 с. 2. Лисиченко Л. Лексико-семантична система української мови. Харків: ХДПУ ім. Г. С. Сковороди, 1997. 129 с. З. Овчаренко Н. До питання специфіки терміна у контексті викладання курсу «Сучасне українське ділове мовлення. Українська мова. Теорія і практика. Донецьк: ДДУ, 1997. 120 с. 4. Олексенко О. Типологія граматично зв’язаних значень слів : навчальний посібник для студентів філологічних факультетів. Харків: ХДПУ, 1999. 136 с. 5. Панько Т. Українське термінознавство: підручник. Львів: Світ, 1994. 216 с. 6. Плотников Б. Основы семасиологии. Минск: Выш. шк., 1984. 223 с. 7. Реформатский А. Что такое термин и термінология. Вопросы терминологии. Москва, 1961. С. 46-54. 8. Суперанская А. Терминология и номенклатура. Проблематика определений терминов в словарях разных типов. Ленинград: Наука, 1976. С. 73-83. 9. Филин Ф. О лексико-семантических группах слов. Езиковедски изследвания в чест на академик Стефбан Младенов. София: Бълг. акад. на науките, 1957. С. 527-528. 10. Шафиков С. Теория семантичесеого поля и компонентной семантики его единиц. Уфа,1999. 88 с.

\section{REFERENCES}

1. Danilenko, V. \& Volkova, I. (1993). Lynhvystycheskyy aspect standardizatsyi terminology [Linguistic aspect of terminology standardization]. Moskva: Nauka [in Russian]. 2. Lysychenko, L. (1997). Lexicyco-semantyshna systema ucrainskoi movy [Lexico-semantic system of the Ukrainian language]. Kharkiv: KhDPU im. H. S. Skovorody [in Ukrainian]. 3. Ovcharenko, N. (1997). Do pytannya spetsyfiky termina u konteksti vykladannya kursu 
«Suchasne ukrayinske dilove movlennya» [To the question of the specifics of the term in the context of teaching the course «Modern Ukrainian business language»]. Ukrayinska mova. Teoriya i praktyka - Ukrainian language. Theory and practice, (pp. 45-48). Donetsk: DDU [in Ukrainian]. 4. Oleksenko, O. (1999). Typolohiya hramatychno zvyazanykh znachen sliv [Typology of grammatically related word meanings]. Kharkiv: KHDPU [in Ukrainian]. 5. Panko, T. (1994) Ukrayinske terminoznavstvo [The Ukrainian terminology]. Lviv: Svit [in Ukrainian]. 6. Plotnikov, B. (1984). Osnovy semasiologii [Basics of semasiology]. Minsk: Vysh. shk. [in Russian] 7. Reformatskiy, A. (1961). Chto takoe termin i terminologiya [What is a term and terminology]. Voprosy terminologii - The question of terminology, (pp. 46-54). Moskva [in Russian]. 8. Superanskaya, A. (1976). Terminologiya i nomenklatura [Terminology and nomenclature]. Problematika opredelenij terminov $v$ slovaryax raznyx tipov - Problems of definitions of terms in dictionaries of different types, (pp. 73-83). Leningrad: Nauka [in Russian]. 9. Filin, F. (1957). O leksiko-semanticheskix gruppax slov [About lexical and semantic groups of words]. Ezikovedski izsledvaniya $v$ chest na akademik Stefan Mladenov - Language studies in honor of the academician Stefan Mladenov, (pp. 527528). Sofiya [in Bulgarian]. 10. Shafikov, S. (1999). Teoriya semanticheseogo polya $i$ komponentnoj semantiki ego edinic [Theory of the semantic field and component semantics of its units]. Ufa [in Russian].

Книшенко Наталія Петрівна - кандидат філологічних наук, доцент, доцент кафедри українознавства, Харківський національний автомобільно-дорожній університет; вул. Ярослава Мудрого, 25, м. Харків, 61000, Україна.

Tel.: +38-095-584-89-08

E-mail: knishenko@meta.ua

http://orcid.org/0000-0002-0803-2774.

Knyshenko Natalya - Ph.D in Philology, Associate Professor, Department of Ukrainian studies, Kharkiv National Automobile and Highway University; Jaroslava Mudrogho Str. 25, Kharkiv, 61000, Ukraine. 